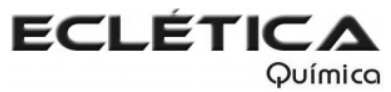

www.scielo.br/eq

www.ecletica.iq.unesp.br

Volume 33, número 4, 2008

\title{
Synthesis and characterization of solid 2-methoxycinnamylidenepyruvic acid
}

\author{
C. T. de Carvalho ${ }^{l}$, A. B. Siqueira ${ }^{l}$, E. Y. Ionashiro ${ }^{2}$, M. Pivattol, M. Ionashiro ${ }^{\prime *}$. \\ ${ }^{1}$ Instituto de Química, UNESP, CP 355, CEP 14801-970, Araraquara, SP, Brazil. \\ ${ }^{2}$ Instituto de Química, UFG, Campus II, CEP74001-979, Goiânia, GO, Brazil. \\ *massaoi@iq.unesp.br
}

\begin{abstract}
The 2-methoxycinnamylidenepyruvic acid (2-MeO-HCP) was synthesized and characterized for nuclear magnetic resonance $\left({ }^{1} \mathrm{H}\right.$ and ${ }^{13} \mathrm{C}$ NMR), mass spectrometry (MS), Infrared spectroscopy (FTIR) and differential scanning calorimetry (DSC). The application of DSC for purity determination is well documented in literature and is used in the analysis of pure organic compounds. The molecular geometry and vibrational frequencies of 2-MeO-HCP have been calculated.
\end{abstract}

Keywords: 2-methoxycinnamylidenepyruvic acid; synthesis; MS; NMR; IR.

\section{Introduction}

Various procedures concerning the preparation of $\alpha$-keto acids have been reported in the literature. ${ }^{1}$ The $\alpha$-keto acids are of continuing interest as model substrates of enzymes, intermediates in chemical syntheses, in the development of enzyme inhibitors and drugs and in other ways. ${ }^{1}$ The aldol condensation products between cinnamaldehyde and pyruvic acid as, 4-dimethylamino and cinnamylidenepyruvic acids has also been described in the literature ${ }^{2,3}$.

Extensive experimental and theoretical investigations have focused on elucidating the structure and normal vibrations of organic compounds ${ }^{4}$. Thus, calculations of optimal molecular geometry and vibrational of 2-MeO-HCP were made. The calculated harmonic frequencies are usually higher than the corresponding experimental quantities, due to a combination of electron correlation effects and basis set deficiencies. It is well known that Hartree-Fock (HF) method tends to overestimate vibrational frequencies.
However, density functional theory (DFT) calculations are reported to provide excellent vibrational frequencies of organic compounds if the calculated frequencies are scaled to compensate for the approximate treatment of electron correlation for basis set deficiencies and the anharmonicity. 5

In this paper, the 2-MeO-HCP was investigated by means of infrared spectroscopy (IR), mass spectrometry (MS), nuclear magnetic resonance (NMR) spectroscopy and differential scanning calorimetry (DSC). The results allowed us to acquire information about these compounds in the solid state. The DSC purity determination method was established using melting point $\left(122{ }^{\circ} \mathrm{C}\right)$ observations revealing a relation between a substance's melting point and its purity ${ }^{6}$.

The optimisation of the DSC purity determination method was done by Blaine et al. ${ }^{7}$ using a Nacional Institute of Standards and Technology (NIST) purity standard - phenacetin doped with $p$-aminobenzoic acid - in 1984. As a result of their investigations, the experimental parameters 
influencing purity results were assessed: specimen size, heating rate, level of impurity. An optimal specimen size $(1.7 \mathrm{mg})$ and heating rate $\left(0.5-2{ }^{\circ} \mathrm{C} \mathrm{min}^{-1}\right)$ were deduced.

The 2-methoxycinnamaldehyde, $\left(\mathrm{CH}_{3} \mathrm{O}\right.$ $\left.\mathrm{C}_{6} \mathrm{H}_{4}-(\mathrm{CH})_{2}-\mathrm{CHO}, 96 \%\right)$ predominantly trans, was obtained from Aldrich and sodium pyruvate $\left(\mathrm{H}_{3} \mathrm{C}-\mathrm{CO}-\mathrm{COONa}, 99 \%\right)$ was obtained from Sigma. 2-methoxycinnamylidenepyruvic acid (2$\mathrm{MeO}-\mathrm{HCP}$ ) was synthesized following the same procedure as described in literature, ${ }^{8}$ with some modifications, as follows: an aqueous solution of sodium pyruvate $(1.5 \mathrm{~g}$ per $10 \mathrm{~mL})$ was added dropwise with continuos stirring to a methanolic solution of 2-methoxycinnamaldehyde (2.0 g per $50 \mathrm{~mL}$ ). Five millilitres of an aqueous sodium hydroxide solution $1.25 \mathrm{~mol} \mathrm{~L}^{-1}$ was added slowly while the reacting system was stirred and cooled in an ice bath. The rate of addition of alkali was regulated so that the temperature remained between 5 and $9{ }^{\circ} \mathrm{C}$. The system was stirred at ambient temperature $\left(\sim 28{ }^{\circ} \mathrm{C}\right)$ for about $5 \mathrm{~h}$. To the pale yellow solution was added dropwise with continuous stirring with a glass rod, twenty millilitres of chilled concentrated $\left(12 \mathrm{~mol} \mathrm{~L}^{-1}\right)$ hydrochloric acid. The system was left to stand for ca. $16 \mathrm{~h}$ in a freezer $\left(-6{ }^{\circ} \mathrm{C}\right)$ and the yellow orange precipitate (impure 2-MeO-HCP) was filtered, washed with distilled water to remove most of the unreacted aldehyde and secondary products and dried on Whatman $\mathrm{n}^{\circ} 44$ filter paper. The aqueous suspension of the impure acid was dissolved with $5 \mathrm{~mL}$ of aqueous sodium hydroxide solution $2 \mathrm{~mol}$ $\mathrm{L}^{-1}$ and filtered on Whatman $\mathrm{n}^{\circ} 44$ filter paper. The yellow solution was stirred with a glass rod and added slowly $20 \mathrm{~mL}$ of chilled concentrated (12 mol L-1) hydrochloric acid and left to stand for ca. $16 \mathrm{~h}$ in freezer $\left(-6^{\circ} \mathrm{C}\right)$. The orange precipitate of $2-\mathrm{MeO}-\mathrm{CP}$ was filtered and washed with distilled water until elimination of chloride ions and dried on Whatman $\mathrm{n}^{\circ} 44$ filter paper and kept in a desiccator over anhydrous calcium chloride. (yield $=$ $28,6 \%$ ).

\section{General methods}

Infrared spectra for 2-MeO-HCP were run on a Nicolet Model Impact 400 FTIR instrument within the $4000-400 \mathrm{~cm}^{-1}$ range. The solid samples were pressed into $\mathrm{KBr}$ pellets.
DSC curve were obtained with DSC Q10 from TA Instruments. The purge gas was an air flow of $50 \mathrm{~mL} \mathrm{~min}^{-1}$. A heating rate $0.5 \mathrm{~K} \mathrm{~min}^{-1}$ for the DSC was adopted, with samples weighing about $1,5 \mathrm{mg}$. Aluminium crucibles with perforated covers were used for the DSC.

The $1 \mathrm{D}-\left({ }^{1} \mathrm{H},{ }^{13} \mathrm{C}\right.$ and DEPT $)$ and $2 \mathrm{D}-$ $\left({ }^{1} \mathrm{H}-{ }^{1} \mathrm{H} g \mathrm{COSY}, g \mathrm{HMQC}\right.$ and $\left.g \mathrm{HMBC}\right) \mathrm{NMR}$ experiments were recorded on a Varian INOVA 500 spectrometer $(11.7 \mathrm{~T})$ at $500 \mathrm{MHz}\left({ }^{1} \mathrm{H}\right)$ and $125 \mathrm{MHz}\left({ }^{13} \mathrm{C}\right)$ at $30{ }^{\circ} \mathrm{C}$ and referenced using TMS as internal standard or residual solvent resonances of $\mathrm{CDCl}_{3}$ at $\delta 7.20$ and 77.0, respectively, for ${ }^{1} \mathrm{H}$ and ${ }^{13} \mathrm{C}$ NMR.

High resolution mass spectra with ESI ionization was measured on UltrO-TOF instrument (Bruker Daltonics) operating in positive mode. $\mathrm{MeOH} / \mathrm{H}_{2} \mathrm{O}$ (4:1) was applied as solvent system.

\section{Purity determination}

The determination of purity is based on the assumption that an impurity will depress the melting point of a pure material whose melting is characterized by a melting point $\left(T_{0}\right)$ and an enthalpy of fusion $\left(\Delta H_{\text {fus. }}\right)$. The effect of an impurity on $T_{\mathrm{o}}$ of the $2 \mathrm{MeO}-\mathrm{HCP}$ was determined by DSC method basing on the Van't Hoff equation (1).

$$
T_{s}=T_{o}-\frac{R T_{o}^{2} x}{\Delta H_{f u s}} \frac{1}{F}
$$

Where $T_{\mathrm{s}}$ is the sample temperature at equilibrium $(\mathrm{K}), T_{\mathrm{o}}$ is the melting point of the pure component $(\mathrm{K}), R$ is the gas constant, $x$ is the concentration of impurity (mole fraction) and $F$ is the fraction molten at $T_{\mathrm{s}}$.

The obtained DSC curve exhibits the endothermic event corresponding to 2-MeO$\mathrm{HCP}$ melting point $\left(\Delta H_{\text {fus }}=+23.36 \mathrm{~kJ} \mathrm{~mol}^{-1}\right)$. The value of purity found was confirming low impurity content.

\section{Structure elucidation}

The molecular weight of 2-MeO-HCP, see Figure 1, was calculated from HRESIMS instrument operating in positive mode. The molecular formulae was established as $\mathrm{C}_{13} \mathrm{H}_{12} \mathrm{O}_{4}$, with a hydrogen deficiency index of eight. The 
observed cationized adduct ion peaks at $\mathrm{m} / \mathrm{z}$ $233,0815[\mathrm{M}+\mathrm{H}]^{+}$and $m / z, 255,0630[\mathrm{M}+\mathrm{Na}]^{+}$ were calculated for $\mathrm{C}_{13} \mathrm{H}_{13} \mathrm{O}_{4}, 233,0814$ and $\mathrm{C}_{13} \mathrm{H}_{12} \mathrm{O}_{4} \mathrm{Na}$, 255,0633, respectively. The ${ }^{1} \mathrm{H}$ NMR analysis of 2-MeO-HCP showed signals for a methoxy group at $\delta 3.90\left(3 \mathrm{H}, \mathrm{s}, \mathrm{H}-7^{\prime}\right)$, four aromatic hydrogen signals at $\delta 6.92(1 \mathrm{H}, \mathrm{dd}, J=$ $8.0 ; 1.0 \mathrm{~Hz}, \mathrm{H}-3$ ') 7.35 ( $1 \mathrm{H}$, ddd, $J=8.0 ; 8.0 ; 1.0$ Hz, H-4'), 6.98 (1H, ddd, $J=8.0 ; 8.0 ; 1.0 \mathrm{~Hz}, \mathrm{H}-$ 5'), and $7.53(1 \mathrm{H}, \mathrm{dd}, J=8.0 ; 1.0 \mathrm{~Hz}, \mathrm{H}-6$ '), respectively, were indicative of a 1,2-disubstituted aromatic system, in addition to four other olefinic hydrogen signals at $\delta 7.05(1 \mathrm{H}, \mathrm{d}, J=$ $15.5 \mathrm{~Hz}), 7.96(1 \mathrm{H}$, ddd, $J=15.5 ; 11.2 \mathrm{~Hz})$, $7.10(1 \mathrm{H}$, ddd, $J=15.5 ; 11.2 \mathrm{~Hz})$, and $7.53(1 \mathrm{H}$, $\mathrm{d}, J=15.5 \mathrm{~Hz}$ ), which were assigned to $\mathrm{H}-3, \mathrm{H}-$ 4, H-5 and H-6, respectively, see Figure 1. Analysis of the ${ }^{1} \mathrm{H}-{ }^{1} \mathrm{H}$ COSY NMR spectrum allowed to confirm the assignment of the signals, see Table 1. The ${ }^{13} \mathrm{C}$ NMR and DEPT spectra displayed 13 signals, including a methoxy group, eight methines, and four quaternary carbons (Table 1). The aromatic carbons signals were identified at $\delta 124.4$ (C-1'), 158.2 (C-2'), 111.3 (C-3'), 131.7 (C-4'), 120.9 (C-5') and 128.3 (C6'). The presence of a conjugated carbonyl and a vicinal carboxylic carbonyl group were indicated by the chemical shifts at 182.0 (C-2) and 160.6 (C-1), respectively, in the ${ }^{13} \mathrm{C}$ NMR spectrum of this compound, in addition to four other olefinic carbons at $\delta 120.4(\mathrm{C}-3), 152.8(\mathrm{C}-4), 127.2$ (C5), and 142.3 (C-6) (Table 1). The aromatic ring was attached to the olefinic end-carbon (C-6), and this was evidenced by the observed $g \mathrm{HMBC}$ correlations between the signal at $\delta 7.53(\mathrm{H}-6)$ and that at $\delta 158.2\left(\mathrm{C}^{\prime} 2^{\prime}\right)$, as well as between the signal at $\delta 7.53$ (H-6') and C-6 ( $\delta$ 142.3). Further more the 1,2-dissubstituted aromatic ring was confirmed by the correlations between the signal at $\delta 3.90\left(\mathrm{OCH}_{3}-7^{\prime}\right)$ with $\mathrm{C}-2$ ' $(\delta$ 158.2) (Table 1). The $E$-configuration of the conjugated double bonds C-3-C-4 and C-5-C-6 in the olefin moiety were determined by the large coupling constant $(15.5 \mathrm{~Hz})$ between $\mathrm{H}-3-\mathrm{H}-4$ and $\mathrm{H}-$ 5-H-6. The structure of $\mathrm{H}-2-\mathrm{MeO}-\mathrm{CP}$ was therefore assigned as $(3 E, 5 E)-6$-(2-methoxyphenyl)2-oxohexa-3,5-dienoic acid.

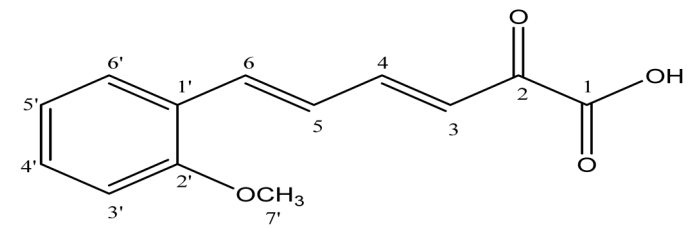

Figure 1. Plane structure of 2-MeO-HCP.

Table 1. MR Spectroscopic Data of H-2MeO-CP in $\mathrm{CDCl}_{3}{ }^{a}$.

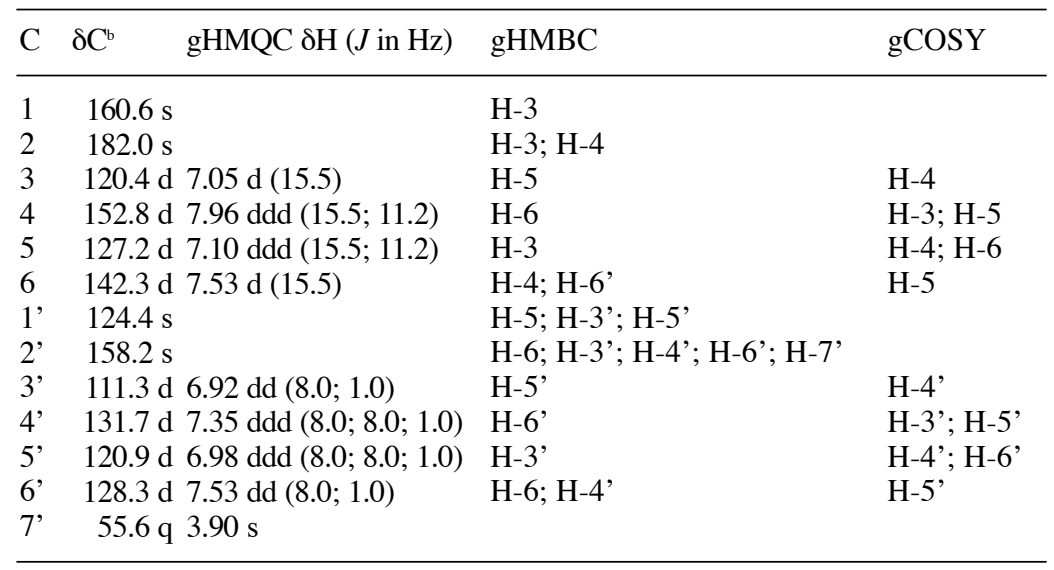

${ }^{a}$ Recorded at 500 and $125 \mathrm{MHz}$ for ${ }^{1} \mathrm{H}$ and ${ }^{13} \mathrm{C}$ NMR, respectively. ${ }^{b}$ Internal standard TMS, $\delta_{\mathrm{TMS}}=0.00$. 


\section{Computational Strategy}

In the present investigation, the employed quantum chemical approach to determining the molecular structures was Becke three-parameter hybrid method $^{9}$ using the Lee-Yang-Par (LYP) correlation functional ${ }^{10}$ and the basis sets used for calculations were the 6-311G. ${ }^{11,12}$ The performed molecular calculations in this work were done using the Gaussian 03 routine. ${ }^{13}$

Molecular structure of the compound could not be determined by the single crystal Xray diffraction technique, a geometry optimization was computed using the optimized algorithm of Berny. 14

Theoretical infrared spectrum was calculated using a harmonic field ${ }^{15}$ based on $\mathrm{C}_{1}$ symmetry (electronic state $\left.{ }^{1} \mathrm{~A}\right)$. Frequency values (not scaled), relative intensities, assignments and description of vibrational modes are presented. The calculations of vibrational frequencies were also implemented to determine an optimized geometry constitutes minimum or saddle points. The principal infrared-active fundamental modes assignments and descriptions were done by the Gauss View 3.0 graphics routine. ${ }^{16}$

The optimized structure parameters of 2$\mathrm{MeO}-\mathrm{HCP}$ dimer calculated by ab initio DFTB3LYP levels with the 6-311G basis set are listed in Table 2 in accordance with the atom numbering scheme given in Figure 2.

Optimized geometries and vibrational modes for studied molecular structures were compared with the experimental frequencies. The optimized geometric parameters (bond lengths and bond angles) obtained, see Table 2, did not can be compared with experimental parameters because the crystal structure of the title compound is not available until now. The Mulliken atomic charges, dipole moment and theoretically computed energies are gather in Table 3. Taking into account that the molecular geometry of the dimer alone in vapor phase may be different from that dimer in the solid phase, owing to extended hydrogen bonding and stacking interactions there is reasonable agreement between the calculated and experimental geometric parameters. As discussed by Johnson et al. ${ }^{17}$, DFT method predicts bond lengths which are systematically too long, particularly the $\mathrm{CH}$ bond lengths.
Table 2. Theoretical geometries parameters of 2$\mathrm{MeO}-\mathrm{HCP}$ compound.

\begin{tabular}{|c|c|c|c|}
\hline Bond lengths $(\AA)$ & & $<\mathrm{H} 53-\mathrm{C} 8-\mathrm{H} 54$ & 109.3 \\
\hline $\mathrm{d} C 1-\mathrm{C}^{\mathrm{a}}$ & 1.41 & $<\mathrm{C} 12-\mathrm{C} 11-\mathrm{C} 10$ & 125.0 \\
\hline $\mathrm{d} C 2-\mathrm{C} 3$ & 1.42 & $<\mathrm{C} 11-\mathrm{C} 10-\mathrm{C} 9$ & 122.2 \\
\hline $\mathrm{d} C 3-\mathrm{C} 4$ & 1.40 & $<\mathrm{C} 10-\mathrm{C} 9-\mathrm{C} 2$ & 127.5 \\
\hline $\mathrm{d}$ C5 - C6 & 1.39 & $<\mathrm{C} 9-\mathrm{C} 2-\mathrm{C} 1$ & 123.1 \\
\hline $\mathrm{d}$ C1 - C6 & 1.39 & $<\mathrm{C} 9-\mathrm{C} 2-\mathrm{C} 3$ & 119.3 \\
\hline $\mathrm{d} C 2-\mathrm{C} 9$ & 1.46 & $<\mathrm{C} 2-\mathrm{C} 3-\mathrm{C} 4$ & 120.5 \\
\hline $\mathrm{d}$ C9 - C10 & 1.35 & $<\mathrm{C} 3-\mathrm{C} 4-\mathrm{C} 5$ & 120.1 \\
\hline $\mathrm{d}$ C10 - C11 & 1.43 & $<\mathrm{C} 4-\mathrm{C} 5-\mathrm{C} 6$ & 120.5 \\
\hline $\mathrm{d}$ C11 - C12 & 1.35 & $<\mathrm{C} 5-\mathrm{C} 6-\mathrm{C} 1$ & 119.4 \\
\hline $\mathrm{d}$ C12-C13 & 1.46 & $<\mathrm{C} 6-\mathrm{C} 1-\mathrm{C} 2$ & 122.0 \\
\hline $\mathrm{d}$ C13 - C15 & 1.55 & $<\mathrm{C} 3-\mathrm{O} 7-\mathrm{C} 8$ & 119.3 \\
\hline $\mathrm{d}$ C3 - O7 & 1.36 & $<\mathrm{H} 36-\mathrm{O} 17-\mathrm{C} 15$ & 127.2 \\
\hline $\mathrm{d}$ C8 - O7 & 1.42 & $<\mathrm{H} 35-\mathrm{O} 16-\mathrm{C} 15$ & 110.2 \\
\hline $\mathrm{d}$ C15 - O16 & 1.31 & $<\mathrm{H} 14-\mathrm{C} 13-\mathrm{C} 12$ & 125.7 \\
\hline $\mathrm{d}$ C15 - O17 & 1.23 & $<\mathrm{H} 14-\mathrm{C} 13-\mathrm{O} 15$ & 119.5 \\
\hline $\mathrm{d} \mathrm{C13}-\mathrm{O} 14$ & 1.22 & $<\mathrm{H} 51-\mathrm{C} 12-\mathrm{C} 11$ & 121.6 \\
\hline $\mathrm{d}$ C12 - H51 & 1.08 & $<\mathrm{H} 51-\mathrm{C} 12-\mathrm{C} 13$ & 117.7 \\
\hline $\mathrm{d}$ C11 - H37 & 1.09 & $<\mathrm{H} 37-\mathrm{C} 11-\mathrm{C} 12$ & 117.3 \\
\hline $\mathrm{d}$ C10 - H42 & 1.09 & $<\mathrm{H} 37-\mathrm{C} 11-\mathrm{C} 10$ & 117.6 \\
\hline d C9 - H43 & 1.09 & $<\mathrm{H} 42-\mathrm{C} 10-\mathrm{C} 11$ & 116.9 \\
\hline $\mathrm{d} C 1-\mathrm{H} 58$ & 1.08 & $<\mathrm{H} 42-\mathrm{C} 10-\mathrm{C} 9$ & 120.9 \\
\hline d C6 - H57 & 1.08 & $<\mathrm{H} 43-\mathrm{C} 9-\mathrm{C} 10$ & 117.4 \\
\hline d C5 - H56 & 1.09 & $<\mathrm{H} 43-\mathrm{C} 9-\mathrm{C} 2$ & 115.2 \\
\hline d C4 - H55 & 1.08 & $<\mathrm{H} 58-\mathrm{C} 1-\mathrm{C} 2$ & 119.1 \\
\hline d C $8-\mathrm{H} 52$ & 1.10 & $<\mathrm{H} 58-\mathrm{C} 1-\mathrm{C} 6$ & 119.0 \\
\hline d C8 - H53 & 1.10 & $<\mathrm{H} 57-\mathrm{C} 6-\mathrm{C} 1$ & 120.1 \\
\hline d C8 - H54 & 1.09 & $<\mathrm{H} 57-\mathrm{C} 6-\mathrm{C} 5$ & 120.4 \\
\hline d O16- H35 & 0.99 & $<\mathrm{H} 56-\mathrm{C} 5-\mathrm{C} 6$ & 120.3 \\
\hline d O17 - H36 & 1.73 & $<\mathrm{H} 56-\mathrm{C} 5-\mathrm{C} 4$ & 119.3 \\
\hline Bond angles $\left({ }^{\circ}\right)$ & & $<\mathrm{H} 55-\mathrm{C} 4-\mathrm{C} 5$ & 119.4 \\
\hline$<\mathrm{O} 16-\mathrm{C} 15-\mathrm{O} 17$ & 125.1 & $<\mathrm{H} 55-\mathrm{C} 4-\mathrm{C} 3$ & 120.6 \\
\hline$<\mathrm{C} 15-\mathrm{C} 13-\mathrm{O} 14$ & 119.5 & $<\mathrm{O} 7-\mathrm{C} 3-\mathrm{C} 4$ & 123.5 \\
\hline$<\mathrm{C} 15-\mathrm{C} 13-\mathrm{C} 12$ & 114.8 & $<\mathrm{O} 7-\mathrm{C} 3-\mathrm{C} 2$ & 116.1 \\
\hline$<\mathrm{C} 13-\mathrm{C} 12-\mathrm{C} 11$ & 120.7 & $<\mathrm{H} 52-\mathrm{C} 8-\mathrm{O} 7$ & 111.4 \\
\hline$<\mathrm{H} 53-\mathrm{C} 8-\mathrm{O} 7$ & 111.4 & $<\mathrm{H} 54-\mathrm{C} 8-\mathrm{O} 7$ & 105.7 \\
\hline$<\mathrm{H} 53-\mathrm{C} 8-\mathrm{H} 52$ & 109.6 & & \\
\hline
\end{tabular}

Key: $\mathrm{H}-2-\mathrm{MeO}-\mathrm{CP}=2$-methoxycinnamylidenepyruvic acid; $\mathrm{d}=$ bond lengths; $<=$ bond angles;

a Atom numbering accord Figure 2.

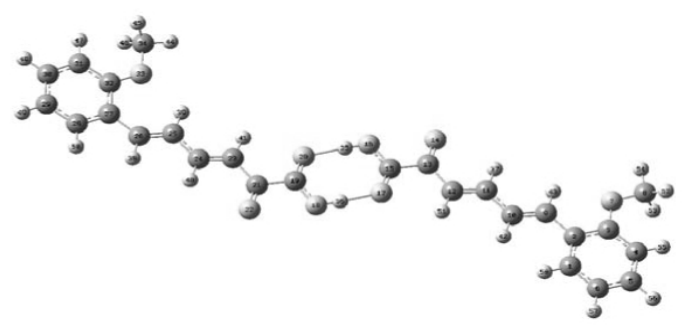

Figure 2. Theoretical 3D structure of solid-state of the 2-MeO-HCP dimer optimized using Becke three-parameter hybrid method, 6-311g basis set of Gaussian 03. 
Table 3. Mulliken atomic charges and additional parameters calculated in B3LYP/6-311g level.

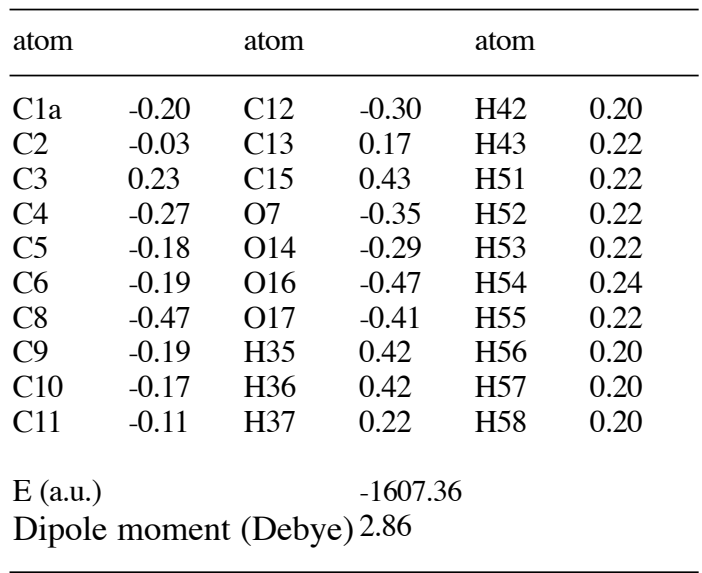

${ }^{a}$ Atom numbering accord Figure 2

The experimental and theoretical IR spectra of $2-\mathrm{MeO}-\mathrm{HCP}$ are given in Figure 3. The resulting vibrational frequencies for the optimized geometries and the proposed vibrational assignments are given in Table 4. Comparisons between theoretical and experimental IR spectra indicated that vibrations were more intense in experimental than theoretical spectrum.

For 2-MeO-HCP group the vibrational modes are $\mathrm{C}-\mathrm{H}$ stretch, $\mathrm{C}=\mathrm{O}$ stretch, $\mathrm{O}-\mathrm{H}$ stretch, $\mathrm{O}-\mathrm{CH}_{3}$ stretch, $\mathrm{CH}_{3} \mathrm{O}-\mathrm{C}_{\mathrm{ar}}$ stretch, C-C stretch, $\mathrm{C}_{\mathrm{co}^{-}}$ $\mathrm{C}_{\text {coo }}$ stretch, $\mathrm{C}-\mathrm{C}-\mathrm{C}$ bending, $\mathrm{CH}_{3}$ bending, $\mathrm{C}-\mathrm{H}$ bending, $\mathrm{COO}$ bending and ring bending.

$\mathrm{O}-\mathrm{H}$ stretching band is characterized by very broad band appearing near about $2500-3600$ $\mathrm{cm}^{-1}$. This may be due combined effect of intermolecular hydrogen bonding. The $\mathrm{O}-\mathrm{H}$ in plane bending vibration occurs in general at $1440-1395 \mathrm{~cm}^{-1}$. The $\mathrm{O}-\mathrm{H}$ out of plane bending vibration occurs in 960-875 $\mathrm{cm}^{-1} .18$ In 2-MeO-HCP, O-H stretching were assigned at 3309 and $3358 \mathrm{~cm}^{-1}$, and in plane and out of plane bending vibrations were assigned at 1385 and $957 \mathrm{~cm}^{-1}$, respectively. Theoretically computed values $\left(3300,1400\right.$ and $\left.970 \mathrm{~cm}^{-1}\right)$ were in agreement with experimental results.

The main feature of carboxylic group is a single band observed usually in the 1700-1800 $\mathrm{cm}^{-1}$ region. ${ }^{18}$ This band is due to the $\mathrm{C}=\mathrm{O}$ stretching vibration. Theoretically computed value of $\mathrm{C}=\mathrm{O}\left(1750 \mathrm{~cm}^{-1}\right)$ band show is agreement with experimental data $\left(1760 \mathrm{~cm}^{-1}\right)$.

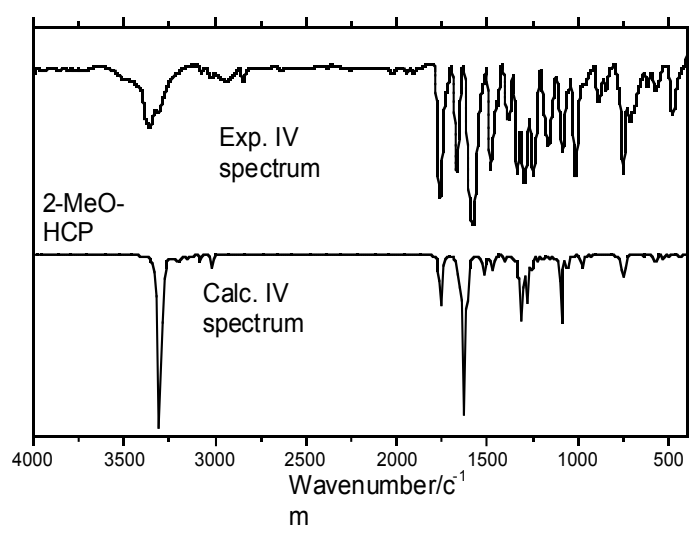

Figure 3. Experimental and calculated IR spectra of 2-MeO-HCP.

Experimental vibration frequencies were in agreement with that theoretically calculated, see Table 4.

\section{Conclusion}

In conclusion, 2-MeO-HCP purity was determined for DSC and structural elucidation was made by MS, NMR and IR. Theoretical infrared spectra was calculated and compared with experimental data. The difference between the observed and scaled wavenumbers values of most of the fundamentals is very small. Any discrepancy noted between the observed and the calculated frequencies may be due to the fact that the calculations have been actually done on a single molecule contrary to the experimental values recorded in the presence of intermolecular interactions. Therefore, the assignments made at higher levels of theory with only reasonable deviations from the experimental values, seem to be correct.

\section{Acknowledgements}

The authors thanks Dr. Éder Tadeu Gomes Cavalheiro - IQ-USP São Carlos - SP for the computational facilities.

Received September 042008

Accepted October 292008 
Table 4. Wavenumbers $\left(\mathrm{cm}^{-1}\right)$, intensities and assignments of bands occurring in the IR spectra of 2-MeO-HCP. The theoretical wavenumbers were calculated in B3LYP/6-311g level.

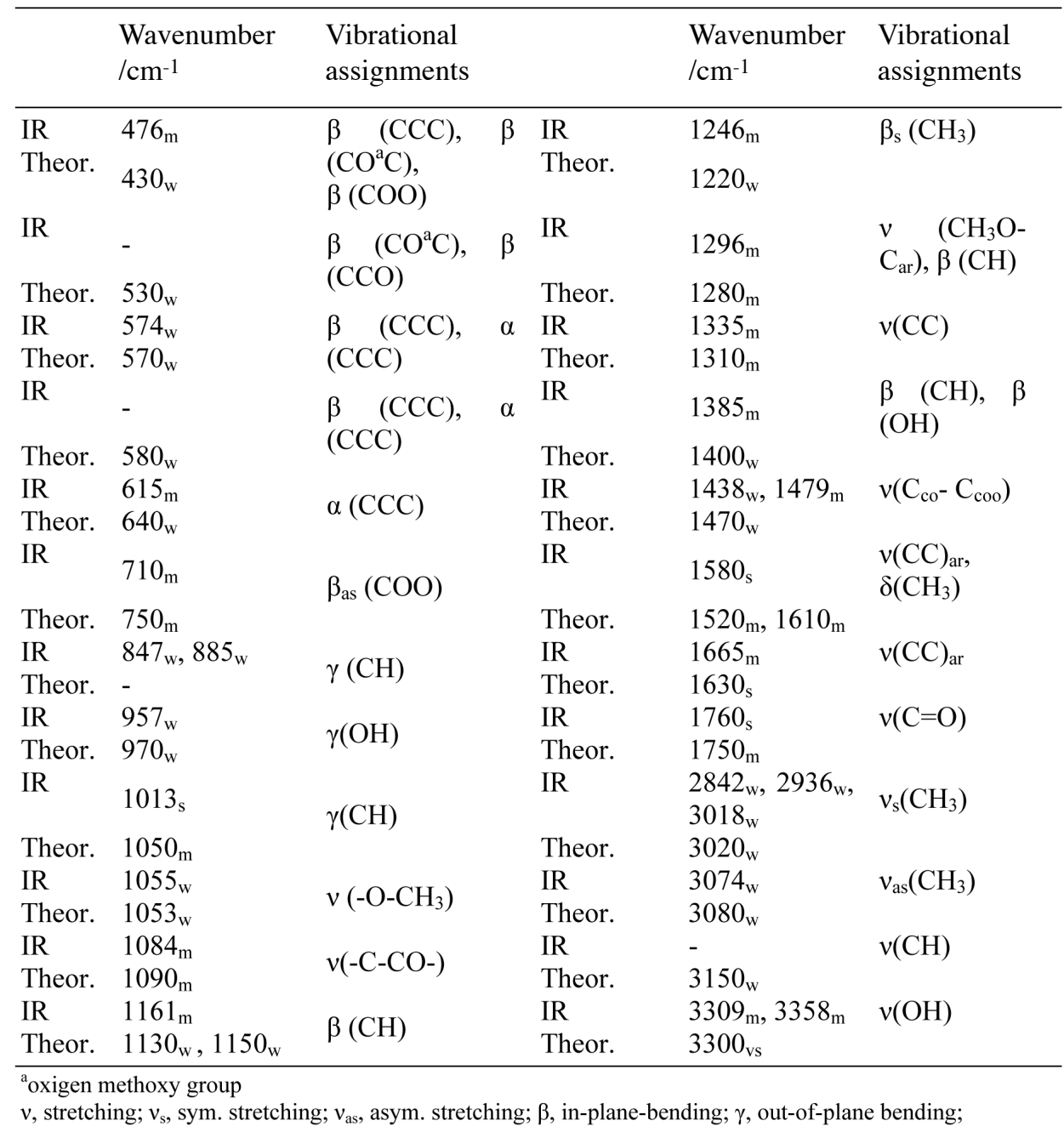

C. T. de Carvalho, A. B. Siqueira, E. Y. Ionashiro, M. Pivatto, M. Ionashiro. Síntese e caracterização do ácido 2-metoxicinamalpirúvico.

Resumo: O ácido 2-metoxicinamalpirúvico (2-MeO-HCP) foi sintetizado e caracterizado por ressonância magnética nuclear $\left({ }^{1} \mathrm{H}\right.$ and $\left.{ }^{13} \mathrm{C} \mathrm{NMR}\right)$, espectrometria de massas (MS), espectroscopia na região do infravermelho (FTIR) e calorimetria exploratória diferencial (DSC). A técnica DSC foi usada para determinação da pureza do composto e as principais bandas de absorção na região do infravermelho foram atribuídas utilizando-se o programa GaussView 3.0.

Palavras-chaves: ácido 2-metoxicinamalpirúvico; síntese; MS; NMR; IR. 


\section{References}

[1] Cooper,A. J. L.; Ginos, J. Z.; Meister, A. Chem. Rev. $1983,83,321$.

[2] Lubrzynska, E.; Smedley, I. Biochem. J. 1913, 7, 375.

[3] Melios, C. B.; Torres, V. R.; Mota, M. H. A.; Tognolli, J. O.; Molina, M. Analyst 1984, 109, 385.

[4] Kalinowska, M.; Swislocka, R.; Lewandowski , W. J. Mol. Struct. 2006, 792-793, 130.

[5] Karabacak, M.; Çınar, M.; Kurt, M. J. Mol. Struct 2008, $885,28$.

[6] Marti, E. Thermochim, Acta 1972, 5, 173.

[7] Hunter, J. E.; Blaine, R. L. ASTM STP 838, American Society of Testing and Materials 1983, 29.

[8] Bannach, G.; Schnitzler, E.; Treu Filho, O.; Utuni, V. H. S.; Ionashiro,M. J. Therm. Anal. Cal., 2006, 83, 233.

[9] Becke, A.D. J. Chem. Phys 1993, 98, 5648.

[10] Lee, C.; Yang, W.; Parr, R.G. Phys. Rev. 1988, B 37, 785. [11] McLean, A. D.; Chandler, G. S. J. Chem. Phys 1980, 72, 5639 .

[12] Krishnan, R.; Binkley, J. S.; Seeger, R.; Pople, J. A . J. Chem. Phys. 1980, 72, 650.

[13] Frisch, M. J.; Trucks, G. W.; Schlegel, H. B.; Scuseria, G. E.; Robb, M. A.; Cheeseman, J. R.; Montgomery Jr., J. A.; Vreven, T.; Kudin, K. N.; Burant, J. C.; Millam, J. M.; Iyengar, S. S.; Tomasi, J.; Barone, V.; Mennucci, B.; Cossi, M.; Scalmani, G.; Rega, N.; Petersson, G. A.; Nakatsuji, H.;
Hada, M.; Ehara, M.; Toyota, K.; Fukuda, R.; Hasegawa, J.; Ishida, M.; Nakajima, T.; Honda, Y.; Kitao, O.; Nakai, H.; Klene, M.; Li, X.; Knox, J. E.; Hratchian, H. P.; Cross, J. B.; Adamo, C.; Jaramillo, J.; Gomperts, R.; Stratmann, R. E.; Yazyev, O.; Austin, A. J.; Cammi, R.; Pomelli, C.; Ochterski, J. W.; Ayala, P. Y.; Morokuma, K.; Voth, G. A.; Salvador, P.; Dannenberg, J. J.; Zakrzewski, V. G.; Dapprich, S.; Daniels, A. D.; Strain, M. C.; Farkas, O.; Malick, D. K.; Rabuck, A. D.; Raghavachari, K.; Foresman, J. B.; Ortiz, J. V.; Cui, Q.; Baboul, A. G.; Clifford, S.; Cioslowski, J.; Stefanov, B. B.; Liu, G.; Liashenko, A.; Piskorz, P.; Komaromi, I.; Martin, R. L.; Fox, D. J.; Keith, T.; Al-Laham, M. A.; Peng, C. Y.; Nanayakkara, A.; Challacombe, M.; Gill, P. M. W.; Johnson, B.; Chen, W.; Wong, M. W.; Gonzalez, C.; Pople, J. A. Gaussian 03, Revision B.04, Gaussian, Inc., Pittsburgh PA, 2003.

[14] Schelegel, H.B. In New Theoretical Concepts for Understanding Organic Reactions; Bertran, J., Ed,; Academic: The Netherlands, 1989, pp. 33-53.

[15] Goodson, D.Z. J. Phys. Chem 1988, 86, 659.

[16] Dennington II, R.; Keith, T. J. M.; Eppinnett, K.; Hovell, W. L.; Gilliland, R. Semichem, Inc., Shawnee Mission, KS, 2003.

[17] Johnson, B.G.; Gill, P.M.; Pople, J.A.; J. Chem. Phys. 1993, 98, 5612.

[18] Sundaraganesan, N.; Joshua, B.D.; Settu, K.; Spectrochim. Acta A 2007, 66, 381. 